\title{
The Effect of 2011 Revised Code of Corporate Governance on Pricing Behaviour of Nigerian Auditors
}

\author{
Salau O. Abdulmalik - Ayoib Che Ahmad
}

\begin{abstract}
:
The paper examines the extent which risk management committee and corporate governance committee predict audit fees in Nigeria. We employed random panel data (unbalance) regression analysis to establish whether risk management committee and corporate governance committee affect audit fees. We obtained the data used for this study from the annual reports of public listed companies on the Nigerian Stock Exchange for the periods 2008-2013. Our results indicate a positive relationship between establishment of risk management committee and audit fees while the establishment of corporate governance committee has an insignificant relationship with audit fees. The findings provide evidence to inform policy makers and corporation in Nigeria on how their governance structure affects audit fees. Firms with a strong governance structure have the incentive to improve the quality of their financial report. Therefore, such firms will increase the scope of auditor's work. This result has implication for policy makers because it suggests that corporate governance mechanisms are important in ensuring a quality audit. The paper contributes to literature on audit pricing in the context of the Nigerian audit market that is currently under-researched. The study provides additional theoretical insights by investigating the impact of risk management committee and corporate governance committee on audit fees, which to the best of the researcher's knowledge, have not been tested in the audit fees model.
\end{abstract}

Key words: Audit fees; Risk management committee; Corporate governance committee.

JEL classification: M42.

\section{Introduction}

Various international economic reports indicate that the Sub-Saharan African economy ${ }^{1}$ is one of the fastest growing economies in the world. Nigeria takes a central place in this growing economy. Being the most populous Black African nation and the seventh most populous country in the world, it is not surprising that Nigeria presents itself as a strategic foreign investment destination in which the capital market plays a vital role. By implication, the quality of financial statement,

Salau O. Abdulmalik; Research Student; School of Accountancy, Universiti Utara Malaysia, Kedah Darul Aman, 06010 UUM Sintok, Malaysia, <abdmaliksalau@ gmail.com>.

Ayoib Che Ahmad; Professor; School of Accountancy, Universiti Utara Malaysia, Kedah Darul Aman, 06010 UUM Sintok, Malaysia.

1 According to International Monetary Fund reports, the region's growth is expected to continue at an expanded rate from five percent in 2014 to 5.75 percent in 2015. 
which could be reduced by excessive audit fees ${ }^{2}$, remains an important component in building a more vibrant capital market. This is because the reliability, transparency, objectiveness and availability of financial information have a profound effect on the stability of the capital market (Bromilow \& Berlin, 2005). In turn, corporate governance effectiveness influences the reliability, transparency, objectiveness and availability of financial information (Zaman et al., 2011).

Owing to the significance of corporate governance, many nations across the globe are compelled to improve corporate governance practices and Nigeria is not an exception. The essence of corporate governance reforms is to enhance financial reporting structure of companies (Beasley et al., 2009; Cohen et al., 2004; Krishnan \& Visvanathan, 2009; Turley \& Zaman, 2007). Aside from the fact that corporate governance reforms have an impact on reporting quality, it also affects the pricing behaviour of auditors (DeFond \& Zhang, 2014). The underlying theoretical justification is that the fear of reputational damage and litigation risk that might arise from financial statement failure due to regulatory reform will cause the board of directors to be more thorough in their process and demand for high quality audit (Zaman et al., 2011).

In this paper, we address the issue of audit pricing in Nigeria by identifying some of the provisions of the new code of corporate governance in Nigeria. Therefore, we seek to understand how these provisions affect audit fees across non-financial listed companies in Nigeria. Specifically, we investigate the influence of risk management committee, corporate governance committee on audit fees using a sample of 427 company-year observations ${ }^{3}$ during the periods of 2008-2013, drawn from a sample of 94 non-financial listed companies on the Nigerian Stock Exchange. After controlling board characteristic, ownership structure and other firm specifics, we found a significantly positive relationship between risk management committee and audit fees. This finding implies that the existence of risk management committee strengthens board monitoring mechanisms. As a result, firms that establish risk management committee expand the scope of auditor's work to reduce possible litigation risk arising from reporting failure. Hence, the increase in audit fees charges. On the contrary, the relationship between corporate governance committee and audit fees is positive but not significant. This result suggests that the activities of corporate governance committee do not affect audit fees. On the overall, this finding suggests that risk management committee is a crucial control mechanism that can complement the audit committee in ensuring audit quality.

2 Excessive audit fees leads to auditor's independence impairment according to the auditor economic bond theory.

3 Unbalanced panel data. 
Our paper extends and contributes to prior literature in some ways. Firstly, while research on audit fees is abundant, no prior studies, to the best of our knowledge, has examined the link between the existence of risk management committee and corporate governance committee on the pricing behaviour of auditors. In fact, again, to the best of our knowledge, there is no empirical evidence on audit fees determinants in Nigeria. We tried to extend prior research that has focused mainly on the firm's governance attributes, such as board composition and audit committee, by investigating the effects of some of the newly introduced provisions in the 2011 revised code of corporate governance as it affects audit pricing behaviour of Nigerian auditors. To the best of our knowledge, this paper is the first to provide empirical evidence on the pricing behaviour of auditors in the Nigeria context.

Secondly, several contemporary studies have developed an audit fee model which cuts across different countries. A substantial number of these studies have concluded that the key determinants of audit fees are auditee-client size, complexity of work, audit risk and governance mechanisms. Nevertheless, the inherent difference in audit risk and corporate governance requirements that varies across countries limits the findings of these previous studies. In addition, the corporate governance code, its implementation and enforcement vary from country to country and are in accordance with prevailing ownership structure ${ }^{4}$. Our study focuses on a less regulated environment where share ownership is concentrated in the hands of foreign institutional investors ${ }^{5}$ and a substantial number of listed companies (locally owned listed companies included) have foreign directors on their boards. This is unique when compared to previous studies (Haniffa et al., 2006) which to the best of our knowledge have used multinational companies.

The remainder of this paper is organised as follows. The next section presents an overview of corporate governance development in Nigeria, followed by theoretical background and literature review in section 3. Section 4 outlines the research design. Sections 5 and 6 present the findings and conclusion, respectively.

4 For instance, in the UK and USA ownership is more diverse; in Germany and Japan, institutional concentrated ownership by banks and non-banks is prevalent; while in Asia and European countries, family concentrated ownership is more prevalent (Shleifer \& Vishny, 1997).

5 Percentages of foreign institutional ownership from 2007 until 2012 are: 14.8\% (2007), 16.5\% (2008), 31\% (2009), 36.1\% (2010), 66.8\% (2011), and 59.9\% (2012) (Proshare News, 2013). 
Abdulmalik, S. O. - Ahmad, A. C.: The Effect of 2011 Revised Code of Corporate Governance on Pricing Behaviour of Nigerian Auditors.

\section{Overview of corporate governance development in Nigeria}

The passage of the Sarbanes Oxley (SOX) Act of 2002 is touted as a revolutionary invention in corporate governance across the globe. Practically, public attention raised by SOX has caused other sovereign states to strengthen the existing code or implement corporate governance code where none existed before. This calls to attention the importance of sound governance practices in ensuring accountability and transparency of the financial reporting process. In Nigeria, corporate governance is not totally a new term as the Companies and Allied Matters Act 1990 as amended in 2004 (CAMA) primarily provides the legal framework for running the affairs of public listed companies. This legal framework follows the Anglo-Saxon model of corporate governance due to the country's history. However, combined with global events in financial reporting cycle and activities of some recognized institutional bodies, there is a renewed emphasis for an effective corporate governance practice. Corporate governance emerged as a "distinct concept" (OFO, 2012) in Nigeria with the issuance of the first Nigerian Code of Corporate Governance (NCCG) in the year 2003 by the Nigeria Securities and Exchange Commission (SEC). So far, most of the provisions contained in the NCCG, regulations and requirements currently in practice in Nigeria are sourced from key provisions of the Organisation for Economic Cooperation and Development (OECD) on principles of corporate governance and other international corporate governance reports.

The 2003 code identified the weaknesses in the existing system and made recommendations based on international best practices. Its introduction is aimed at stimulating accountability and transparency in the financial reporting process and as a guide to improve board effectiveness (Okike, 2007). Specifically, the code spells out the requirement for strengthening the board with respect to composition and size, appointment of directors, board meetings and the board's fiduciary responsibilities. With respect to board composition, the code recommends that the board should be made up of both executive and non-executive directors and the board size should be determined in accordance with individual company's need. Similarly, the role of the chairman and that of the Chief Executive Officer (CEO) must be held by two separate individuals so as to preserve board independence. However, where the same individual holds the two positions, then it is required that independent non-executive directors should dominate the board. Without doubt, the 2003 code is the forerunner to the development of other sectors' code of corporate governance ${ }^{6}$ and the 2011 revised NCCG.

6 Corporate Governance for Banks in Nigeria Post-Consolidation (2006 CBN); Code of Corporate Governance for Licensed Pension 2008 (PENCOM 2008) and Code of Corporate Governance for National Insurance Commission 2009 (NICOM 2009). 
As part of its continuous effort to strengthen corporate governance practices, the SEC issued a new code on the 1st of April 2011. The new code has significant provisions in addition to those in existence before. Key among the provisions are the need to have at least one financial expert on the audit committee and the presence of at least one independent non-executive director on the board. In addition, the 2011 revised code of corporate governance recommends that all public listed companies should establish risk management committee and corporate governance committee to strengthen further the financial reporting and internal control processes. The CAMA 2004 empowers the board of directors to establish committees as needs dictate. Specifically, section 64 (a) permits the board of directors to carry out its statutory functions through board committees consisting of such members as they think fit. In essence, the 2011 revised code of corporate governance reinforces transparency and promotes accountability through good corporate governance practices (SEC Code, 2011). Although the code of corporate governance makes detailed provisions to enhance investors' trust in the market, compliance with the code is voluntary. The SEC has the power of enforcement and sanctioning erring listed companies, although this SEC role has not been efficiently performed over the past few years.

In enforcing the NCCG, just like anywhere else in the world, auditors play a prominent role. Their primary role is to lend credibility to the financial information given to investors (Okike, 2004). Given this role, the external auditor is required to obtain appropriate training, gain necessary experience and be ethically bound to maintain some level of professionalism (Okike, 2004) and independence. In performing his or her role, the auditor assesses the client's overall internal reporting environment and reaches a conclusion on his or her audit risk exposure. The cost of auditor risk exposure and auditor's effort is the audit fees paid by the client.

\section{Theoretical background and literature review}

Many of the issues on corporate governance studies are linked to the separation of owners from those who make managerial decisions. The cost of separating ownership from control and the possible ways to mitigate those costs dominate corporate governance discussion (Jensen \& Meckling, 1976). An example of such a cost is agency cost. Managers possess superior inside information when compared to the information available to shareholders (Pong \& Whittington, 1994). Since managers possess superior information, they have the incentive to enhance personal utility at the expense of maximizing shareholders' wealth (Berle $\&$ Means, 1932). Therefore, in order to minimize the resulting consequences, a number of corporate governance mechanisms are available to monitor managerial behaviour. Among these mechanisms are the board of directors and its subcommittees and the external auditor (Agarwal \& Knoeber, 1996). Mainly, the 
board of directors performs an arbitrator's role, by reconciling the conflicting interests of the shareholders and controlling managers. In the case of the external auditor, he or she adds credibility to financial reporting quality. How well the external auditor performs his or her role and how the client reporting environment affects auditor's incentive structure and quality of reporting have been areas of concern in academic literature.

Quite a number of empirical researches are available on audit market. A particular concern is on auditor's incentive structure (Pong \& Whittington, 1994; Simunic, 1980). Several studies from both developed (Simunic, 1980; Chan et al., Pong \& Whittington, 1994; Firth, 1985) and developing (Joshi \& Al-Bastaki, 2000; Naser \& Nuseibeh, 2007; Ahmed \& Goyal, 2005) countries have developed models to explain factors that cause variation in audit fees. The seminal work of Simunic (1980) provides evidence, which suggests that two factors, namely, auditor's effort and post-audit litigation risk, affect the level of audit fees. These two factors, commonly proxied for client size, client complexity, client risk, year-end accounts, auditor type and industry, are measures of audit scope, complexity and risk. Irrespective of country, prior studies have convincingly agreed that these proxies explain variation in audit fees.

Another proxy in the literature is corporate governance quality. Studies that have examined the relationship between audit fees and corporate governance quality offer mixed findings. These mixed findings stem from the variations in corporate governance regulations and its implementation among countries (Zaman et al., 2011). Companies in developed countries, like the UK and the US, are subject to more stringent corporate governance requirements with respect to board composition, board meetings and audit committee structure. In addition, there are two conflicting views, namely, the agency theory view and the audit production view available in literature to explain the relationship between both. These views also account for the mixed evidence (Knechel \& Willekens, 2006).

For instance, Abbott (2003); Boo and Sharma (2008); Goodwin-Stewart (2006); O'Sullivan (2000); and Zaman et al. (2011) present evidence in support of the agency theory view. According to the agency theorists, corporate governance quality will lead to more demand by clients with respect to audit scope from the auditor, and hence, higher audit fees. Abbott et al. (2003); Carcello et al. (2002); Goodwin and Kent (2006); and Mitra et al. (2007) find a positive relationship between audit fees and independent directors, suggesting that independent directors demand more from auditors in order to protect their reputational capital. The production view argument, on the other hand, takes into account clients' inherent and control risk (Knechel \& Willekens, 2006). 
The production view states that the strength of the client reporting environment (i.e., internal control) in curbing financial reporting irregularities, determines auditor detection risk. Therefore, a strong corporate governance environment can reduce the number of substantive and compliance test needed by the auditor, and hence, a reduction in audit fees (Cohen \& Hanno, 2000). Consistent with this view, Bliss (2011) reports that large board portend risk to auditors; hence, auditors charge more audit fees for firms with large boards. Boo (2008), on the other hand, documents an insignificant relationship between board size and audit fees. Tsui et al. (2001) reveal that boards with CEOs whose influence dominates the board are less effective in discharging their monitoring role. As a result, auditors take extra effort and time to audit firms with powerful CEOs, which in turn, increases audit fees. Mitra et al. (2007) document an insignificant relationship between CEO duality, board expertise, board meetings, and audit fees.

In addition to board effectiveness, previous studies have investigated the impact of audit committee characteristic on audit fees. Abbot et al. (2003); Mitra et al. (2007); and Goodwin-Stewart \& Kent (2006) document a positive relationship between audit committee characteristic and audit fees. Yatim et al. (2006) document a positively significant relationship between audit committee expertise, frequency of meetings and external audit fees. Yatim's findings support the agency theory view. From the agency perspective, an efficient audit committee will have incentives to ensure high quality audit. However, from the production perspective, an efficient audit committee will strengthen internal control and this could reduce auditor's risk exposure. Subsequently, auditors will rely on client's internal control, leading to less auditor effort and hence, a reduction in audit fees. In line with the audit production perspective, Boo (2008); and Krishnan and Visvanathan (2009) find that financial expertise of audit committee negatively affects audit fees.

A review of several prior related studies has shown that the focus has mainly been on one sub-committee of the board, which is the audit committee. To the researchers' best knowledge, less attention has been paid to other sub-committees, like the risk management committee and corporate governance committee. Currently, the revised corporate governance code has increased the responsibilities of the board of directors and directors face pressure to comply. Given the paucity of research on the relationship between both the risk management and corporate governance committees and audit fees, it is imperative to examine whether the existence of these board committees affects audit fees. Currently, many studies have looked into this aspect in highly regulated markets with little attention being given to less regulated environments. Particularly in Nigeria, to the best of the researchers' knowledge, no study is available on the impact of corporate governance mechanisms on audit fees. 
Abdulmalik, S. O. - Ahmad, A. C.: The Effect of 2011 Revised Code of Corporate Governance on Pricing Behaviour of Nigerian Auditors.

In the following section, we develop two main hypotheses on the relationship between the presence of risk management and corporate governance committees and audit fees. Two other hypotheses test the association among external audit fees and both local and foreign institutional ownership structures.

\section{Establishment of risk management committee and corporate governance committee}

Regulatory reforms (for example, the Sarbanes Oxley Act and Higgs Report), have brought about dramatic changes to corporate governance since the turn of the century. Corporate governance practices have evolved from a box-ticking exercise to more proactive processes, involving risk management and control. The code of corporate governance now seeks for the establishment of a risk management committee. According to the code of corporate governance, risk management committee has an oversight function over a firm's risk management policy, risk tolerance and risk strategy. Risk management has now become an integral part of corporate governance and is linked to internal control. The creation of a risk management committee signals a firm's awareness of the importance of risk management and control (Yatim, 2010). This awareness has resulted in an improved board oversight function, which in turn can enhance the board's governance structure and internal control function, and hence financial reporting quality. Yatim (2010) finds a significant relationship between the establishment of risk management committee and strong board structure. Firms with risk management committee are more thorough when monitoring internal control and have more chances of detecting fraud. In short, the establishment of a risk management committee leads to improved financial reporting quality. From the agency perspective, firms with risk management committee demand for reputable external audit, thus increasing the audit scope and leading to a high quality audit firm being hired in order to reduce litigation risk. Hence, we hypothesize that:

H1: The existence of a risk management committee positively and significantly influences audit fees.

Our second hypothesis relates to the establishment of the corporate governance committee. The committee's principal function includes appointment, remuneration, evaluation of individual board member's performance and establishing a succession plan policy for the CEO and other executive positions (SEC Code, 2011). Other things being constant, it would be expected that a board with greater oversight on its remuneration and nomination functions would want to attract and retain individuals of good quality, for example, those with independent minds. Carson (2002); and Menon and Williams (1994) find that the existence of a nomination committee, as provided for in the code of corporate governance, improves board efficiency. A more efficient and effective board from 
the demand perspective will have zero tolerance for audit failure and demand more from external auditors. Consequently, the additional demands by clients will lead to an increase in audit fees. Consistent with this view, we argue that the board of directors will demand for an extensive audit procedure or might seek the services of reputable audit firms. Whichever the option taken, audit fees paid by firms with corporate governance committee are expected to be on the high side. Based on the foregoing theoretical assertion, we postulate that:

$\mathrm{H} 2$ : The existence of a corporate governance committee positively and significantly influences audit fees.

\section{Research design}

\subsection{Sample}

The population of our study includes all the 181 companies listed on the Nigerian Stock Exchange as obtained from the exchange website as at 31 December $2013^{7}$. The period covered is 2008 to 2013. However, all companies operating under the financial sector were eliminated due to differences in reporting characteristics and regulatory environment, leaving us with a population of 125 companies, from which 31 companies were excluded because of missing data. This resulted in a final sample of 94 companies ( 75 percent), based on which we tested the study's hypotheses. The final study is representative of non-financial listed firms on the Nigerian Stock Exchange. The study is a panel data set survey of six years and after making necessary adjustments, the total number of company observations was 427 (unbalanced panel data) as contained in Table 1 panel A and B below. Both financial and non-financial data were hand-picked from companies' annual report.

\section{Tab. 1: Sample's descriptive statistics}

\begin{tabular}{lll}
\hline \multicolumn{2}{l}{ Panel A: Sample's descriptive statistics according to sector } \\
SECTOR & Freq. & 5 \\
\hline Agriculture & 20 & 15 \\
Conglomerate & 65 & 30 \\
Consumer & 126 & 15 \\
Industrial Goods & 65 & 10 \\
Natural Resources & 44 & 25 \\
Services & 107 & 100 \\
Total & 427 & \\
\hline
\end{tabular}

7 There are currently 192 companies listed on the Nigerian Stock Exchange. but at the time of this study (year 2013), there were just 181 companies. 
Abdulmalik, S. O. - Ahmad, A. C.: The Effect of 2011 Revised Code of Corporate Governance on Pricing Behaviour of Nigerian Auditors.

\begin{tabular}{llc}
\hline $\begin{array}{l}\text { Panel B: Sample's descriptive statistics according to year } \\
\text { YEAR }\end{array}$ & \multicolumn{2}{c}{$\begin{array}{c}\text { No of observation per year } \\
\text { YEAR }\end{array}$} \\
\hline 2008 & 60 & 14 \\
2009 & 66 & 15.5 \\
2010 & 75 & 17.6 \\
2011 & 79 & 18.5 \\
2012 & 77 & 18 \\
2013 & 70 & 16.4 \\
Total & 427 & 100 \\
\hline
\end{tabular}

Source: Authorial computation.

\subsection{Dependent variable}

Based on our theoretical framework and the hypotheses, the conceptual model of audit pricing introduced by Simunic (1986), and as extended by Chan et al. (1993); and Boo and Sharma (2008) was adopted in this study. We used a panel data regression model to examine the relationship among ownership variables and corporate governance variables and audit fees. Panel data regression approach offers some benefits as noted by Henderson \& Kaplan (2000): (i) it allows construction of models that are more sophisticated than time series and crosssectional models when repeated measure of a sample is involved; and (ii) it addresses the econometric issues of omitted variable bias and heterogeneity bias. Accordingly, the panel regression model as provided below was developed. In line with past studies (Francis \& Simon, 1987), the natural log transformation of audit fees (LOGFEES) measured by the Naira value of the audit fees paid by the firm to its auditor represents our dependent variable. The audit fees figure is disclosed under the notes to the accounts in the companies' annual report.

\subsection{Independent variables}

The independent variables are the presence of the risk management committee (RISKCOM), the corporate governance committee (CORPCOM). Presence of RISKCOM is a dummy variable with 1 denoting the presence of risk management committee. CORPCOM is a dummy variable and 1 denoting the presence of a corporate governance committee.

\subsection{Control variable}

The audit fees model used in other extant studies introduce different firm specific variables to control for cross-sectional differences among listed companies. Audit fees are associated with auditee size, auditee complexity and auditee riskiness (Simunic, 1980; Carcello \& Neal, 2002; Abott et al., 2003). Past studies have provided evidence suggesting that these variables have good explanatory power and robustness across countries studied at different points in time. 
Consistent with previous studies, this study adopted size, complexity, client risk and, audit quality as having high predictive power. We controlled for size effect using the natural $\log$ transformation of turnover (LOGTOVER). We expect a positive relationship between firm size and audit fees because audit scope and effort increase with the size of the company, resulting in higher audit fees (Simunic, 1986). Similarly, the study took into account the natural log transformation of ratio of inventory to total assets (LOGRITA) and the number of subsidiaries (SUB1) plus one to control for audit complexity (Ahmad et al., 2006; Simunic, 1986). We posit a positive relationship between the proxies of auditee complexity and audit fees; the implication of this being that more subsidiaries and high proportion of inventory to total assets ratio will result in greater amount of audit effort (Chan et al., 1993; Mustapha \& Ahmad, 2011). We also include the ratio of return on assets (ROA), i.e., net profit before tax over total assets to control for auditee riskiness. We expect high audit risk to result in higher audit fees due to further audit testing or insurance coverage (Chan et al., 1993). Finally, a dummy variable for big audit firms (BIG4) was included in our model to take into account differences in audit quality (Gul, 2006; Yatim et al., 2006). DeAngelo (1981); and Carcello et al. (2002), observed variation in the quality of services rendered by audit firms.

In addition to the above, board related controls introduced in our model are boardsize (BSIZE), measured by the total number of directors, both executive and nonexecutive, sitting on the board; foreign directors (FDIRECT) measured as the number of foreign directors sitting on each company's board and audit committee diligence (ADILI) measured by the number of times the audit committee met during the fiscal year. Ownership related controls are foreign institutional ownership (FSHR), local institutional ownership (INSTITSHR). FSHR and INSTITSHR are continuous variables. These variables represent the percentage of foreign institutional ownership and percentage of both local and foreign institutional ownership in the company's outstanding shares, while foreign directors represent.

\section{Model specification}

We use the following panel equation model to analyze the relationship between dependent variable and the independent variables.

$$
\begin{aligned}
& \text { LOGFEES }_{i t}=\alpha_{i}+\beta 1 \text { RISKCOM }_{i t}+\beta 2 \text { CORPCOM }_{i t}+\beta 3 \text { SSHR }_{i t} \\
& +\beta \text { IINSTITSHR }_{i t}+\beta 5 \text { FDIRECT }_{i t}+\beta 6 \text { BSIZE }_{i t} \\
& +\beta 7 \text { ADILI }_{i t}+\beta 8 \text { LOGTOVER }_{i t}+\beta 9 \text { ROA }_{i t}+\beta 10 \text { LOGRITA }_{i t} \\
& +\beta 11 \text { NOSUB }_{i t}+\beta 12 B I G 4_{i t}+\mu_{i t}+\varepsilon_{i t}
\end{aligned}
$$

Where $\mathrm{i}$ is index of the cross-sectional unit; $\mathrm{t}$ is index of time; LOGFEES expressed natural logarithm of audit fees; RISKCOM is an indicator variable 1 for 
companies that have established risk management committee; CORPCOM is an indicator variable 1 for companies that have established corporate governance committee; FSHR express the percentage of companies' outstanding shares held by foreign investors; INSTITSHR is the percentage of companies' outstanding shares held by local institutional investors; FDIRECT is the number of foreign directors on board; BSIZE express the number of directors sitting on board; ADILI represent the number of times that audit committee met during the year; LOGTOVER express the natural logarithm of turnover; ROA means return on assets measured by earnings before interest and tax scaled by total assets; LOGRITA means the natural logarithm of ratio of inventory to total assets; NOSUB1represent the number of subsidiaries plus one; BIG4 is an indicator variable equal to 1 if firm is audited by big four audit firm ; ${ }^{\alpha_{i}}$ represent individual effect $; \mu_{i t}$ is the coefficient of explanatory variable; and $\varepsilon_{i t}$ represent error term.

\section{Interpretation of result and discussion of findings}

\subsection{Descriptive statistics}

The descriptive statistics for both the dependent and the independent variables are as disclosed in Table 2. The average FEE (AF) is N16, 423,590 and ranges from $\mathrm{N} 135,000$ to $\mathrm{N} 20$ million. The mean percentage of RISKCOM is about 31 percent and the mean percentage of CORPCOM committee is about 47 percent. FSHR averages 24.26 percent with a range between 0 and 91 percent, while the average number of foreign directors is 1.72 with a minimum of 0 directors and maximum of eight directors. BIG4 auditors audited just over 64 percent of the sample population. The average value estimated for BIG4 is consistent with the result of Adelopo (2011) that revealed 65 percent. Both results suggest the dominance of BIG4 in the Nigerian audit market, while the smaller audit firms took on the remaining 36 percent. The average turnover for the companies in the sample is $\mathrm{N}$ 28 billion. 
Tab. 2: Descriptive statistics for sample firms

\begin{tabular}{lllll}
\hline Variable & Mean & Std. Dev. & Min & Max \\
\hline FEE & 16451.19 & 26232.67 & 135 & 200063 \\
RISKCOM & 0.31 & 0.46 & 0.00 & 1.00 \\
CORPCOM & 0.47 & 0.50 & 0.00 & 1.00 \\
FSHR & 24.26 & 29.81 & 0.00 & 91.00 \\
INSTITSHR & 46.29 & 27.99 & 0.00 & 98.63 \\
FDIRECT & 1.73 & 1.92 & 0.00 & 8.00 \\
BSIZE & 5.71 & 3.00 & 1.00 & 9.00 \\
ADILI & 3.21 & 1.14 & 0.00 & 7.00 \\
TOVER & 28100000 & 53400000 & 24126 & 386000 \\
ROA & 211.01 & 123.38 & 1.00 & 424.00 \\
RITA & 1.54 & 1.66 & 0.00 & 15.80 \\
NOSUB1 & 2.78 & 3.36 & 0.00 & 14.00 \\
BIG4 & 0.64 & 0.48 & 0.00 & 1.00 \\
\hline SOUrCe: Auth & & & & \\
\hline
\end{tabular}

Source: Authorial computation.

\subsection{Correlation analysis}

Table 3 reports on the correlations among the variables of the study. Overall, most of the correlations are less than the threshold value of $0.80^{8}$. This indicates that the degree of multicollinearity among the variables is not severe. FDIRECT is found to be positively correlated with FSHR and negatively correlated with RISKCOM. The negative correlation means that companies with FSHR are less likely to have risk management committee.

8 According to Gujarati (2004), if the pairwise correlation coefficient between two variables is in excess of 0.8 , then multicollinearity is a serious problem. 
Abdulmalik, S. O. - Ahmad, A. C.: The Effect of 2011 Revised Code of Corporate Governance on Pricing Behaviour of Nigerian Auditors.

Tab. 3: Pearson correlation table

\begin{tabular}{|c|c|c|c|c|c|c|c|c|c|}
\hline & FEE & RISKCOM & CORPCOM & FSHR & INSTITSHR & FDIRECT & BSIZE & ADILI & TOVER \\
\hline FEE & 1.00 & & & & & & & & \\
\hline RISKCOM & 0.33 & 1.00 & & & & & & & \\
\hline CORPCOM & 0.19 & 0.49 & 1.00 & & & & & & \\
\hline FSHR & 0.12 & -0.13 & 0.08 & 1.00 & & & & & \\
\hline INSTITSHR & 0.11 & -0.10 & -0.14 & 0.58 & 1.00 & & & & \\
\hline FDIRECT & 0.13 & -0.19 & 0.00 & 0.78 & 0.60 & 1.00 & & & \\
\hline BSIZE & -0.11 & -0.08 & -0.08 & -0.16 & -0.09 & -0.15 & 1.00 & & \\
\hline ADILI & 0.18 & 0.30 & 0.30 & 0.16 & 0.04 & 0.05 & -0.10 & 1.00 & \\
\hline TOVER & 0.62 & 0.13 & 0.09 & 0.23 & 0.22 & 0.32 & -0.17 & 0.11 & 1.00 \\
\hline ROA & 0.17 & -0.04 & -0.14 & 0.22 & 0.18 & 0.20 & -0.06 & 0.04 & 0.40 \\
\hline RITA & -0.06 & -0.18 & -0.06 & -0.27 & -0.24 & -0.20 & 0.06 & -0.25 & -0.22 \\
\hline NOSUB1 & 0.67 & 0.29 & 0.26 & -0.02 & -0.03 & 0.00 & 0.00 & 0.17 & 0.46 \\
\hline BIG4 & 0.28 & 0.11 & 0.16 & 0.20 & 0.03 & 0.02 & -0.04 & 0.16 & 0.26 \\
\hline
\end{tabular}

Tab. 3: Continued

\begin{tabular}{lrrrr}
\hline & ROA & RITA & NOSUB1 & BIG4 \\
\hline & & & & \\
ROA & 1.00 & & & \\
RITA & -0.35 & 1.00 & & \\
Nosub1 & 0.05 & 0.02 & 1.00 & 1.00 \\
BIG4 & 0.22 & -0.29 & 0.20 & \\
\hline
\end{tabular}

Source: Authorial computation.

\subsection{Breusch-Pagan Largrange Test (BP LM)}

The Breusch-Pagan Lagrange was used to test for the presence of individual heterogeneity in order to decide the appropriate model between pooled model and random effect model. Since the null hypothesis is consistent with the assumption of the pooled model, the result of BP LM indicates that we should reject the pooled model in favour of the random effect model.

\subsection{Test for random and fixed effects regression}

In order to choose between the fixed and random effect estimator, the Hausman test was carried out and the results of the Hausman test indicate that random effect of GLS is an appropriate estimator. Therefore, the result of the generalist square random regression is given in the next session.

\subsection{Result of random effect model}

Table 4 reports the random effect result obtained by testing the association between log of audit fees and other experimental variables. The adjusted R2 for the model is 0.7398 and the Prob> Chi is significant at 0.0000 , which suggest that this is a good predictive model of audit pricing behaviour for Nigerian data. The study's R2 is also very high when compared to that in similar studies by Yatim et 
al. (2006) and Wahab et al, (2009) that have 69 percent and 43 percent, respectively.

The independent variable, RISKCOM appears to be in a significantly positive relationship with audit fees at the 1 percent level $(0.001, \mathrm{t}=2.55, \mathrm{p}<0.011)$, the result supports the agency theory perspective. This result implies that risk management committee is a crucial control mechanism that can complement the audit committee in ensuring that external auditors discharge their statutory duty extensively. In fact, the boards of directors of companies with a risk management committee are likely composed of directors with great reputational capital. Therefore, consistent with studies that adopted the agency theory perspective (Abbott et al., 2003; Carcello et al., 2002; Goodwin-Stewart \& Kent, 2006; O'Sullivan, 1999), the positive relationship between risk management and audit fees is due to directors' reputational capital that encourages the demand for more extensive audit to protect them from litigation risk. Hence, the reason for the higher audit fees in companies with risk management committee. For the relationship between corporate governance committee and audit fees, the result in Table 4 shows that the presence of corporate governance committee has a positive but insignificant relationship with audit fees

With respect to control variables, foreign share ownership is negatively insignificant with audit fees. Though not significant, the negative direction indicates the monitoring ability of foreign institutional investors in ensuring sound corporate governance practices. In the case of independent variable, INSTITSHR, the variable is significantly and positively related to audit fees at the 1 percent level ( $\mathrm{t}=3.37, \mathrm{p}<0.001)$. This finding is consistent with prior literature's argument that institutional investors are efficient monitoring mechanisms (Bathala \& Rao, 1995; Desender et al., 2009; Shleifer \& Vishny, 1997; Gorton \& Schmid, 1996). Institutional investors have enough voting rights to ensure the management respects their wishes. Accordingly, consistent with prior studies (O'Sullivan, 2000; Kane \&Velury, 2004; Wahab et al., 2009) that have documented a positive relationship between large institutional shareholding and audit fees, we can assert that Nigeria's institutional shareholders improve corporate governance practices through their demand for high quality audit, hence prompting higher audit fees. We find also that the company related control variables, LOGTOVER, ROA, LOGRITA, NOSUB1 and BIG4 have a significant relationship with LOGAF, consistent with the findings of previous studies. 
Abdulmalik, S. O. - Ahmad, A. C.: The Effect of 2011 Revised Code of Corporate Governance on Pricing Behaviour of Nigerian Auditors.

Tab. 4: Random Effect Result

\begin{tabular}{llll}
\hline LOGAF & Coef. & $\mathbf{z}$ & $\mathbf{P}>\mathbf{z}$ \\
\hline RISKCOM & 0.36 & 2.55 & $0.011^{* * *}$ \\
CORPCOM & 0.08 & 0.58 & 0.56 \\
FSHR & 0.00 & -1.22 & 0.22 \\
INSTITSHR & 0.01 & 3.37 & $0.001^{* * *}$ \\
FDIRECT & 0.04 & 0.70 & 0.49 \\
BSIZE & -0.03 & -1.26 & 0.21 \\
ADILI & 0.10 & 1.98 & $0.048^{* * * *}$ \\
LOGTOVER & 0.44 & 9.08 & $0.000^{* * *}$ \\
ROA & 0.00 & 0.25 & 0.80 \\
LOGRITA & 0.46 & 4.71 & $0.000^{* * * *}$ \\
NOSUB1 & 0.07 & 2.96 & $0.003^{* * *}$ \\
BIG4 & 0.58 & 4.27 & $0.000^{* * *}$ \\
CONS & 0.82 & 1.19 & 0.24 \\
\hline
\end{tabular}

Source: Authorial computation.

Note: $\mathrm{R}$-sq $===0.7398$ Prob $>\mathrm{Chi}===0.0000$ Notes: $*=$ significant at 10 percent, $* *=$ significant at 5 percent and $* * *=$ significant at 1 percent.

\section{Conclusion}

This study examines the effect of the presence of a risk management committee and corporate governance committee on the pricing behaviour of Nigerian auditors. The recent review of the NCCG that is geared towards strengthening corporate governance practices in listed companies and the limited empirical evidence concerning the Nigerian market for audit services, have motivated this study. The first motivation caused the present study to introduce risk management committee and corporate governance committee into the audit fees model. We argue that the presence of the two committees will strengthen internal control process and possibly have substitution effect on the work of the external auditor. However, to the contrary, the result shows that the presence of risk management committee caused an increase in audit fees, which is consistent with the agency theory perspective, which suggests that boards of directors of firms with risk management committee make additional demands to the external auditor to widen the scope of their audit procedure. On the other hand, the presence of corporate governance committee shows a positive but insignificant relationship with audit fees. This possibly could be attributable to poor composition of the committee that might have impeded the committee's independence.

Our result indicates that risk management committee is associated with higher audit fees. The practical implication of these findings is that risk management committee compliment the work of the audit committee. Our result partly supports 
the expectation of the Nigerian SEC that the establishment of risk management committee will enhance board oversight function over firm's compliance with necessary regulatory requirements. Implicitly, the new code of corporate governance will possibly have a consequence for public companies as it may increase the effectiveness and scope of external auditor's monitoring role. However, for the corporate governance committee to have a meaningful impact on external reporting, companies should reconsider the composition of this committee in order to ensure more representation of independent directors in the committee. Overall, the findings of our study suggest an improvement in in both the internal and external monitoring mechanisms partly due to the introduction of risk management committee. However, based on this result regulatory authorities should encourage listed companies that are yet to establish a risk management committee to do so and as well encourage the independence of the corporate governance committee.

This study has potential regional implications as the African sub-region seeks to improve corporate governance practices and auditor's independence. This is particularly so, given the drive of governments in the region to maintain sustainable growth by attracting foreign investors. However, foreign investors from developed and sophisticated markets would require some level of protection in terms of transparent financial disclosure from companies listed in the region. Therefore, the findings from this study create awareness on corporate governance practices in the region and should stimulate further institutional changes that will help achieve sustainable growth within the region, specifically in Nigeria.

Like other empirical work, this research is not without limitations. It is suggested that the findings be interpreted within the purview of the highlighted limitations. First, the sample used in this study is too small, due to problems of data availability at the time of data collection. Most of the annual reports were not available online. In addition, the present study excluded banking and other financial institutions due to their reporting structure. To this extent, the results of the sample may suffer from sample bias. In addition, non-audit fees are lumped together with audit fees in the annual report; consequently, the study used auditor's remuneration. However, the study does not expect this non-separation to affect the result of the study since it is not significant in Nigeria. Hence, our findings should be understood within the caveats mentioned above. We recommend future studies to consider other regulatory changes. Future studies can endeavour to investigate, for instance, the impact of adoption of the International Financial Reporting Standards (IFRS) on reporting quality and how the improved reporting quality affects audit fees. In fact, currently, the Financial Reporting Council of Nigeria (FRCN) mandates that the name of the auditor signing the annual report should appear against the name of the audit firm as previously done, 
Abdulmalik, S. O. - Ahmad, A. C.: The Effect of 2011 Revised Code of Corporate Governance on Pricing Behaviour of Nigerian Auditors.

giving room for further research studies as this should have an interesting effect on the entire audit market.

Similarly, contextual variables that can capture corporate governance practices in Nigeria distinct from what are obtainable anywhere else should be considered in future studies on audit pricing in Nigeria. Such variables can emanate from ownership structure type in the country or the dominance of one ethnic group in the board structure, in line with risk averseness and business shrewdness of each ethnic group. Lastly, consistent with the resource dependence theory, future studies within this regulatory setting, can examine the impact of networking, director's reputation (i.e., politically connected firms) and board's negotiation skills on audit pricing. Probably, these variables can serve to explain the variations in audit fees better within the Nigerian context.

\section{References}

Abbott, L. J., Parker, S., Peters, G. F., Raghunandan, K,. 2003. The association between audit committee characteristics and audit fees. Auditing 2, 17-32.

Adelopo, I., 2011. Voluntary disclosure practices amongst listed companies in Nigeria. Advances in Accounting 2, 338-345.

Agrawal, A., Knoeber, C. R., 1996. Firm performance and mechanisms to control agency problems between managers and shareholders. Journal of Financial and Quantitative Analysis 3, 377-397.

Ahmad, A. C., Houghton, K. A., Yusof, N. Z. M., 2006. The Malaysian market for audit services: Ethnicity, multinational companies and auditor choice. Managerial Auditing Journal 7, 702-723.

Ahmed, K., Goyal, M. K., 2005. A comparative study of pricing of audit services in emerging economies. International Journal of Auditing 2, 103-116.

Aswadi Abdul Wahab, E., Mat Zain, M., James, K. and Haron, H., 2009. Institutional investors, political connection and audit quality in Malaysia. Accounting Research Journal 2, 167-195.

Bathala, C. T., Rao, R. P., 1995. The determinants of board composition: An agency theory perspective. Managerial and decision economics 1, 59-69.

Beasley, M. S., Carcello, J. V., Hermanson, D. R., Neal, T. L., 2009. The Audit Committee Oversight Process. Contemporary Accounting Research 1, 65-122.

Berle, A., Means, G., 1932. The modern corporate and private property. McMillian, New York, NY.

Bliss, M. A., 2011. Does CEO duality constrain board independence? Some evidence from audit pricing. Accounting \& Finance 2, 361-380. 
European Financial and Accounting Journal, 2015, vol.10, no. 4, pp. 45-65.

Boo, E. F., Sharma, D., 2008. Effect of regulatory oversight on the association between internal governance characteristics and audit fees. Accounting \& Finance 1, 51-71.

Bromilow, C. L., Berlin, B., 2005. Audit Committee Effectiveness. Corporate Board, 16.

Carcello, J. V., Neal, T. L., 2003. Audit committee independence and disclosure: Choice for financially distressed firms. Corporate Governance: An International Review 4, 289-299.

Carcello, J. V., Hermanson, D. R., Neal, T. L., Riley Jr, R. A., 2002. Board characteristics and audit fees. Contemporary Accounting Research 3, 365-384.

Carson, E., 2002. Factors associated with the development of board subcommittees. Corporate Governance: An International Review 1, 4-18.

Chan, P., Ezzamel, M., Gwilliam, D., 1993. Determinants of audit fees for quoted UK companies. Journal of Business Finance \& Accounting 6, 765-786.

Cohen, J. R., Hanno, D. M., 2000. Auditors' consideration of corporate governance and management control philosophy in preplanning and planning judgments. Auditing: A Journal of Practice \& Theory 2, 133-146.

DeFond, M., Zhang, J., 2014. A review of archival auditing research. Journal of Accounting and Economics 2, 275-326.

Desender, K. A., 2009. The Relationship Between the Ownership Structure and Board Effectiveness. University of Illinois at Urbana-Champaign, College of Business Working Papers, 9-105.

Firth, M., 1985. An Analysis of Audit Fees and their Determinants in NewZealand. Auditing: A Journal of Practice \& Theory 2, 23-37.

Francis, J.R. and Simon, D.T., 1987. A test of audit pricing in the small-client segment of the US audit market. Accounting Review, 145-157.

Goodwin-Stewart, J., Kent, P., 2006. Relation between external audit fees, audit committee characteristics and internal audit. Accounting \& Finance 3, 387-404.

Gorton, G., \& Schmid, F., 1996. Universal banking and the performance of German corporations. NBER working paper, 5453.

Haniffa, R., Che Ahmad, A., Houghton, K. A., Zalina Mohamad Yusof, N., 2006. The Malaysian market for audit services: ethnicity, multinational companies and auditor choice. Managerial Auditing Journal 7, 702-723.

Henderson, B., Kaplan, S. E., 2000. An Examination of Audit Report Lag for Banks: A Panel Data Approach. Auditing: A Journal Of Practice \& Theory 2, 159.

Jensen, M. C., Meckling, W. H., 1976. Theory of the firm: Managerial behaviour, agency costs and ownership structure. Journal of Financial Economics 4, 305-360. 
Abdulmalik, S. O. - Ahmad, A. C.: The Effect of 2011 Revised Code of Corporate Governance on Pricing Behaviour of Nigerian Auditors.

Joshi, P., AL-Bastaki, H., 2000. Determinants of audit fees: evidence from the companies listed in Bahrain. International Journal of Auditing 2, 129-138.

Kane, G.D. and Velury, U., 2004. The role of institutional ownership in the market for auditing services: an empirical investigation. Journal of Business Research 9, 976-983.

Knechel, W. R., Willekens, M., 2006. The role of risk management and governance in determining audit demand. Journal of Business Finance \& Accounting 9-10, 1344-1367.

Krishnan, G., Visvanathan, G., 2009. Do auditors price audit committee's expertise? The case of accounting versus non accounting financial experts. Journal of Accounting, Auditing \& Finance 1, 115-144.

Menon, K., Williams, J. D., 1994. The use of audit committees for monitoring. Journal of Accounting and Public Policy 2, 121-139.

Mitra, S., Hossain, M., Deis, D., 2007. The empirical relationship between ownership characteristics and audit fees. Review of Quantitative Finance \& Accounting 3, 257-285.

Mustapha, M., Che Ahmad, A., 2011. Agency theory and managerial ownership: evidence from Malaysia. Managerial Auditing Journal 5, 419-436.

Naser, K., Nuseibeh, R., 2008. Determinants of audit fees: empirical evidence from an emerging economy. International Journal of Commerce and Management 3, 239-254.

O'Sullivan, N., 2000. The impact of board composition and ownership on audit quality: Evidence from large UK companies. The British Accounting Review 4, 397-414.

Ofo, N., 2012. Draft Revised Code of Corporate Governance for Banks in Nigeria: Bringing Independent Directors on Board.

Okike, E., 2004. Management of crisis: The response of the auditing profession in Nigeria to the challenge to its legitimacy. Accounting, Auditing \& Accountability Journal 5, 705-730.

Okike, E. N. M., 2007. Corporate governance in Nigeria: The status quo. Corporate Governance: An International Review 2, 173-193

Pong, C. M., Whittington, G., 1994. The determinants of audit fees: Some empirical models. Journal of Business Finance \& Accounting 8, 1071-1095.

Proshare News, 2013. Available from: <http://www.proshareng.com/news/19093>.

Ronen, J., 2002. Policy reforms in the aftermath of accounting scandals, Editorial, Journal of Accounting \& Public Policy, pp. 281-286. Available from: $<$ http://eserv.uum.edu.my/login?url=http://search.ebscohost.com/login.aspx?direct $=$ true $\& \mathrm{db}=$ bah $\& A N=8791789 \&$ site $=$ ehost-live $\&$ scope $=$ site $>$. 
Shleifer, A., Vishny, R. W., 1997. A survey of corporate governance. The journal of finance 2, 737-783.

Simunic, D. A., 1980. The pricing of audit services: Theory and evidence. Journal of Accounting Research 1, 161-190.

Turley, S., Zaman, M., 2007. Audit committee effectiveness: informal processes and behavioural effects. Accounting, Auditing \& Accountability Journal 5, 765788 .

Tsui, J.S., Jaggi, B. and Gul, F.A., 2001. CEO domination, growth opportunities, and their impact on audit fees. Journal of Accounting, Auditing \& Finance 3, 189208.

Yatim, P., Kent, P., Clarkson, P., 2006. Governance structures, ethnicity, and audit fees of Malaysian listed firms. Managerial Auditing Journal 7, 757-782.

Zaman, M., Hudaib, M., Haniffa, R., 2011. Corporate governance quality, audit fees and non-audit services fees. Journal of Business Finance \& Accounting 1/2, 165-197. 